\title{
Apakah Perusahaan BUMN yang telah diprivatiasi memiliki Tata Kelola Perusahaan yang Lebih Baik Dibandingkan dengan Perusahaan Swasta? (Studi pada Perusahaan yang terdaftar di BEI)
}

\author{
Nur Khamisah ${ }^{1}$ \\ Program Studi Akuntansi, Fakultas Ekonomi, Universitas Sriwijaya \\ Inurkhamisah08@fe.unsri.ac.id
}

\begin{abstract}
Abstrak
Penelitian ini menginvestigasi apakah setelah BUMN diprivatisasi, BUMN akan menghasilkan tata kelola perusahaan yang lebih baik dibandingkan dengan perusahaan swasta. Tata kelola perusahaan diukur dengan melakukan skoring pada penerapan tata kelola perusahaan yang dilakukan oleh perusahaan. Sampel penelitian adalah perusahaan-perusahaan yang bergerak di sektor properti, infrastruktur, konsumsi, industry dasar dan pertambangan yang terdaftar di BEI periode 2014-2016. Penelitian ini menggunakan metode purposive sampling dan melakukan analisis uji regresi linier berganda untuk menguji hipotesis penelitian. Sampel akhir penelitian ini terdiri dari 454 tahun observasi perusahaan. Penelitian ini menghasilkan temuan bahwa BUMN yang telah diprivatisasi memiliki tingkat tata kelola perusahaan yang lebih baik dibandingkan dengan perusahaan swasta. Hasil uji regresi menunjukkan koefisien tata kelola perusahaan dan kinerja pasar BUMN bernilai positif dan signifikan di level $1 \%$. Hasil ini secara tidak langsung menunjukkan bahwa strategi privatisasi melalui IPO yang dilakukan oleh pemerintah terhadap beberapa BUMN telah efektif dalam meningkatkan tata Kelola perusahaan BUMN.
\end{abstract}

Kata Kunci: BUMN, Privatisasi, Tata Kelola Perusahaan

\begin{abstract}
This study investigates whether, after SOEs are privatized, they will produce better corporate governance than private companies. Corporate governance is measured by scoring the implementation of corporate governance by the company. The research sample is companies engaged in the property, infrastructure, consumption, basic industry and mining sectors listed on IDX for the 2014-2016 period. This study uses a purposive sampling method and performed multiple linear regression analysis to test the research hypothesis. The final sample of this study consisted of 454 years of company observations. The results of this study find that privatized SOEs have a better level of corporate governance than private companies. The regression test results show the coefficient of corporate governance and the SOE market performance is positive and significant at the level of $1 \%$. These results indirectly indicate that the privatization strategy through IPOs carried out by the government against several SOEs has been effective in improving corporate governance of SOE.
\end{abstract}

Keywords: SOE, Privatization, Corporate Governance

\section{PENDAHULUAN}

Badan Usaha Milik Negara (BUMN) adalah perusahaan yang (seluruhnya atau sebagian) dimiliki dan dikendalikan oleh negara (pemerintah) (Peng et al., 2016). BUMN merupakan aspek penting dari ekonomi dunia, dimana BUMN menyumbangkan sekitar 10\% dari PDB 
global (Bruton et al., 2015). Namun, selama ini kinerja BUMN seringkali dipandang memiliki kinerja yang kurang efisien dibandingkan dengan perusahaan swasta (DeWenter \& Malatesta, 2001). Sekretaris Kementerian BUMN Imam A Putro menuturkan, sepanjang paruh pertama tahun 2017, sebanyak 24 BUMN (21\% dari total 115 BUMN) masih mencatat kerugian (Primadhyta, 2017). Kinerja BUMN saat ini dinilai masih buruk. Kinerja keuangan masih dinilai buruk dapat dilihat dari beberapa BUMN yang masih mengalami kerugian, masih terdapat banyak tindakan korupsi, dan adanya ancaman kepailitan di beberapa BUMN. Hal ini membuat beberapa pihak cenderung akan memandang sebelah mata terhadap kinerja BUMN, dimana BUMN diharapkan dan seharusnya bisa menjadi agen pembangunan sekaligus lokomotif perekonomian nasional.

Terdapat beberapa cara yang dapat dilakukan untuk memperbaiki kinerja BUMN, dari sekedar penjualan aset publik lewat lelang publik atau penjualan langsung dan cara lain yang dianggap tepat. Di Indonesia, strategi privatisasi BUMN merupakan cara yang tepat untuk memperbaiki kinerja (Munawarah et al., 2017).

Privatisasi suatu BUMN di Indonesia dilakukan dengan tujuan salah satunya untuk menciptakan efisiensi ekonomi agar menjadi entitas bisnis yang tangguh dan profesional sehingga memiliki daya saing (Mardiasmo, 2009). Sejak akhir tahun 1990-an, BUMNBUMN di Indonesia mulai melakukan upaya restruktrusasi untuk memperbaiki kinerja perusahaan dan metode yang paling banyak dipilih adalah menjual saham ke pihak swasta (privatisasi). Hal ini dikarenakan menurut Omran (2009) menjual sebagian saham pemerintah ke pihak swasta akan lebih menambah value added perusahaan dan meningkatkan kinerja perusahaan.

Kinerja suatu perusahaan tidak terlepas dari yang namanya tata kelola perusahaan (corporate governance). Corporate Governance merupakan mekanisme yang menjelaskan hubungan pihak-pihak yang berpartisipasi dalam pengelolaan dan kinerja perusahaan. Munawarah et al. (2017) menyatakan bahwa kurang baiknya kinerja BUMN dalam memberikan kontribusi pada pertumbuhan ekonomi nasional dan pendapatan tahunan negara terutama dikarenakan oleh belum meratanya implementasi tata kelola perusahaan yang baik (Good Corporate Governance). 
Salah satu fakta yang memperlihatkan buruknya kinerja BUMN ditemukan oleh Direktorat Jenderal Pajak (DJP), yang menunjukkan bahwa BUMN memiliki kinerja pajak yang rendah. Ditemukan dari 701 wajib pajak (WP) Badan BUMN yang tercatat, baru 28 WP yang telah mengikuti program tax amnesty di tahun 2016, dengan nilai tebusan sebesar Rp13,013 miliar (Kemenkeu, 2016). Menteri Keuangan Sri Mulyani Indrawati menyatakan bahwa hingga pertengahan periode II ini, partisipasi BUMN, anggota komisaris dan direksi BUMN dinilai memalukan (Primadhyta, 2016).

Munawarah et al. (2017) menyatakan bahwa salah satu cara yang dapat dilakukan untuk mengurangi temuan audit potensial dan memperbaiki kinerja BUMN adalah melalui strategi privatisasi. Pernyataan ini didukung oleh hasil yang didapatkan oleh penelitian Munawarah et al. (2017). Penelitiannya menemukan bahwa BUMN yang listed di pasar modal atau BUMN yang telah diprivatisasi memiliki hasil audit yang lebih baik dan implementasi GCG yang lebih tinggi dibandingkan dengan BUMN yang tidak diprivatisasi. Oleh karena itu, terdapat kemungkinan bahwa kinerja keuangan BUMN privatisasi yang ditemukan ternyata lebih unggul dari perusahaan swasta tidak lepas dari implementasi tata kelola perusahaan yang diterapkan.

\section{TINJAUAN PUSTAKA}

\section{Teori Keagenan}

Teori keagenan merupaka teori yang menjelaskan hubungan suatu kontrak dimana satu orang atau lebih (principal) memperkerjakan orang lain (agen) untuk memberikan suatu jasa dan kemudian mendelegasikan wewenang pengambilan keputusan kepada agen tersebut (Jensen dan Meckling, 1976). Hal tersebut terjadi karena terdapat pemisahan kepemilikan dan kontrol, ketika pemilik perusahaan atau dewan direksi (principal) harus mempekerjakan manajer (agen) untuk menjalankan bisnis dan principal perlu untuk memantau kinerja mereka untuk memastikan mereka bertindak sesuai dengan kepentingan pemilik. Perhatian utama dari teori keagenan seperti yang diungkapkan oleh Jensen dan Meckling (1976) adalah bagaimana menulis kontrak dimana kinerja agen dapat diukur secara intensif sehingga mereka bekerja sesuai dengan kepentingan prinsipal. Didasarkan pada ide bahwa karyawan 
pada berbagai tingkat memiliki tujuan yang beragam dan berbeda-beda. Dua masalah keagenan yang diidentifikasi: bagaimana menyelaraskan tujuan yang saling bertentangan antara pihak prinsipal dan agen, dan bagaimana memastikan agen melakukan pekerjaan yang sesuai dengan apa yang diharapkan oleh prinsipal.

\section{Privatisasi BUMN}

Menurut Kepres RI No. 122 tahun 2001, privatisasi adalah pengalihan atau penyerahan sebagian kontrol atas sebuah BUMN kepada swasta antara lain melalui cara penawaran umum, penjualan saham secara kepada karyawan, dan atau cara-cara lain yang dipandang tepat. Selanjutnya, menurut UU No. 19 tahun 2003, privatisasi adalah penjualan saham Persero, baik sebagian maupun seluruhnya kepada pihak lain dalam rangka meningkatkan kinerja dan nilai perusahaan, memperbesar manfaat bagi negara dan masyarakat, serta memperluas pemilikan saham oleh masyarakat.

Tujuan dari privatisasi suatu badan usaha milik negara (BUMN) salah satunya adalah untuk menciptakan efisiensi ekonomi agar menjadi entitas bisnis yang tangguh dan profesional sehingga memiliki daya saing (Mardiasmo, 2009). Privatisasi BUMN juga telah dilakukan di negara-negara lain. Privatisasi BUMN di China telah dimulai sekitar tahun 1990-an. Privatisasi BUMN dilakukan untuk mendorong kenaikan tingkat kompetitif dan konsentrasi FDI industri dan penekanan anggaran (Tong, 2009) Kecepatan untuk mereformasi perusahaan milik negara telah membedakan Cina dari negara-negara ekonomi terpusat lainnya, dan dengan demikian menarik banyak perhatian dalam literatur ekonomi. Privatisasi dilakukan untuk mendorong penyerapan surplus tenaga kerja dan membantu menjaga stabilitas sosial, yang sangat penting bagi keberhasilan fungsi keseluruhan ekonomi (Bai et al., 2009).

\section{Tata Kelola Perusahaan (Corporate Governance)}

Monks (2003) mendefinisikan Good Corporate Governance (GCG) sebagai sistem yang mengatur dan mengendalikan perusahaan yang menciptakan nilai tambah (value added) untuk semua stakeholders. Ada dua hal yang ditekankan dalam konsep ini. Pertama, pentingnya hak pemegang saham untuk memperoleh informasi dengan benar dan tepat pada waktunya dan kedua, kewajiban perusahaan untuk melakukan pengungkapan (disclosure) 
secara akurat, tepat waktu, transparan terhadap semua informasi kinerja perusahaan, kepemilikan, dan stakeholders.

Survey yang dilakukan oleh PricewaterhouseCoopers menemukan bahwa praktik tata kelola perusahaan di Indonesia relatif tidak memadai (PricewaterhouseCoopers, 2000). Survei tersebut menunjukkan bahwa di antara negara-negara di wilayah Asia-Australia, Indonesia berada pada tingkat yang sangat rendah dalam standar disclosure dan transparansi (Kurniawan \& Indriantoro, 2000). Indonesia juga berada pada peringkat yang sangat rendah di bidang lain seperti pertanggungjawaban kepada pemegang saham, proses dewan, audit, dan kepatuhan.

Hasil dari beberapa penelitian mengenai tata kelola perusahaan menunjukkan bahwa komposisi dari dewan perusahaan dan komite audit merupakan mekanisme tata kelola yang penting dalam mempengaruhi kinerja perusahaan. Independensi dewan memainkan peran penting di negara-negara berkembang dan juga pasar negara berkembang (Claessens dan Yurtoglu, 2012).

Komite audit berfungsi sebagai dewan pengawas mewakili dewan komisaris perusahaan. Siregar dan Utama (2008) menyatakan bahwa proporsi sewan independen dan komite audit sering digunakan sebagai proksi praktik tata kelola yang memiliki peran penting dalam menghambat perilaku earnings management. Penerapan GCG di BUMN diharapkan dapat mengurangi perilaku yang mungkin timbul dari kepemilikan pemerintah. Hal ini, pada gilirannya, dapat membantu meningkatkan kinerja dan nilai perusahaan.

\section{Tata Kelola Perusahaan BUMN Privatisasi}

Tong dan Li (2015) menyatakan bahwa terdapat dua pendekatan potensial yang dapat mencapai sistem tata kelola perusahaan yang sesuai di dalam ekonomi peralihan: (1) pendekatan privatisasi dan (2) pendekatan yang dikendalikan oleh pemerintah. Temuan empiris menunjukkan bahwa privatisasi memang telah membawa beberapa keuntungan bagi masyarakat di Cina. Ding et al., (2008) menguji mengenai tindakan earnings management yang dilakukan oleh perusahaan swasta dan BUMN dengan sampel perusahaan di China. Penelitian ini menemukan bahwa perusahaan swasta lebih cenderung akan melakukan earnings management dibandingkan BUMN. Liu et al. (2014) dari penelitiannya mengenai dewan independen dan kinerja perusahaan di China menyatakan bahwa di perusahaan yang 
dikendalikan oleh pemerintah, pemerintah akan menunjuk dewan direksi independen yang lebih kuat sehingga dapat mengurangi insider self-dealing, meningkatkan efisiensi investasi, dan meningkatkan kinerja perusahaan.

Di konteks Indonesia, Kamal (2010) melakukan penelitian mengenai pedoman tata kelola perusahaan di Indonesia menyatakan bahwa pedoman tata kelola perusahaan (code of corporate governance) Indonesia secara konseptual tidak dapat memperbaiki kinerja BUMN murni Indonesia. Hal yang dibutuhkan adalah undang-undang dan peraturan khusus, dan juga pedoman yang kuat yang bebas dari campur tangan politik dan dewan komisaris yang tidak profesional dan dapat mengatasi tujuan pihak-pihak yang bertentangan. Munawarah et al., (2017) meneliti mengenai dampak dari kebijakan privatisasi pada tata kelola perusahaan BUMN Indonesia. Munawarah et al. (2017) menemukan bahwa BUMN yang diprivatisasi memiliki hasil audit yang lebih baik dibandingkan dengan BUMN yang tidak diprivatisasi (pure stated owned enterprise).

Berdasarkan uraian diatas, maka hipotesis yang dapat dikembangkan adalah sebagai berikut.

Hipotesis: BUMN yang diprivatisasi memiliki tingkat tata kelola perusahaan yang lebih baik dibandingkan dengan perusahaan swasta.

\section{METODE PENELITIAN}

\section{Populasi dan Sampel}

Penelitian ini menggunakan perusahaan-perusahaan yang terdaftar di Bursa Efek Indonesia untuk periode 2014 sampai 2016. Pengambilan sampel menggunakan metode purposive sampling dengan beberapa kriteria yang ditentukan. Data keuangan dikumpulkan dari database OSIRIS dan laporan tahunan perusahaan. Perusahaan keuangan dikecualikan dari sampel penelitian ini. 


\section{Tata Kelola Perusahaan}

Tata kelola perusahaan diukur dengan menggunakan proksi GCG Score yang didalamnya terdapat beberapa subindex yang dijadikan acuan dalam menentukan skoring yang antara lain adalah sebagai berikut.

Shareholder Rights / Hak Pemegang Saham (subindex A).

Boards of Directors (subindex B).

Outside Directors (subindex C).

Audit Committee and Internal Auditor (subindex D).

Disclosure to Investors (subindex E).

Subindex A menjelaskan tentang variabel yang digunakan untuk skoring hak para pemegang saham. Subindex B menjelaskan tentang variabel yang digunakan untuk skoring dewan komisaris. Subindex C menjelaskan tentang variabel yang digunakan untuk melakukan skoring komisaris independen. Subindex D menjelaskan tentang variabel yang digunakan untuk melakukan skoring terhadap komite audit dan audit internal. Subindex E menjelaskan variabel yang digunakan untuk skoring terhadap pengungkapan kepada investor. Detail variabel yang digunakan dalam penelitian dapat dilihat pada lampiran 1.

Menurut Black, Jang, dan Kim (2003) masing-masing ukuran dalam subindex diberikan poin 1 jika terpenuhi, dan 0 jika tidak terpenuhi. Untuk memperoleh skor GCG total maka digunakan rumus sebagai berikut.

$$
C G I=A+(B+C) / 2+D+E
$$

\section{Uji Hipotesis}

Setelah dilakukan uji deskriptif dan uji asumsi klasik, selanjutnya data akan diuji lagi untuk menguji hipotesis penelitian yang dikembangkan. Pengujian variabel independen dan variabel dependen pada penelitian ini dilakukan dengan teknik uji regresi linier berganda. 
Model yang diajukan untuk pengujian hipotesis 1, yaitu sebagai berikut.

Model:

$\mathrm{CGI}=\alpha+\beta 1 \mathrm{BUMN}+\beta 2 \mathrm{ROA}+\beta 3 \mathrm{LEV}+\beta 4 \mathrm{SIZE}+\beta 5 \mathrm{GRWTH}+\beta 6 \mathrm{SB}+\varepsilon$

Untuk melihat tata kelola perusahaan dari BUMN privatisasi lebih tinggi dari perusahaan swasta, maka diharapkan nilai $\beta 1$ (koefisien) pada model 1 akan lebih besar dari $0(\beta 1>0)$ dengan signifikansi $\alpha<0,05$. Jika nilai $\beta 1$ (koefisien) pada model 1 adalah lebih besar dari 0 pada tingkat signifikansi $\alpha<0,05$, maka nantinya dapat disimpulkan bahwa BUMN privatisasi memiliki tata kelola perusahaan yang lebih baik dibandingkan dengan perusahaan swasta.

\section{Hasil Penelitian dan Pembahasan}

Berikut ini adalah statistik deskriptif variabel-variabel penelitian yang diolah dengan menggunakan SPSS 21.0 for Windows.

\section{Statistik Deskriptif}

Tabel 1 Statistik Deskriptif Variabel-Variabel Penelitian

\begin{tabular}{|l|c|c|c|c|}
\hline & & $\mathrm{N}$ & Mean & St. Deviation \\
\hline CGI & SWASTA & 413 & 15,77 & 1,74 \\
& BUMN & 41 & 19,06 & 0,67 \\
\hline ROA & SWASTA & 413 & 1,96 & 7,07 \\
& BUMN & 41 & 2,90 & 5,28 \\
\hline LEVERAGE & SWASTA & 413 & 0,50 & 0,36 \\
& BUMN & 41 & 0,56 & 0,18 \\
\hline SIZE & SWASTA & 413 & 21,72 & 1,59 \\
& BUMN & 41 & 23,63 & 1,05 \\
\hline GROWTH & SWASTA & 413 & 10,62 & 55,35 \\
& BUMN & 41 & 23,82 & 28,53 \\
\hline SB & SWASTA & 413 & 14,73 & 1,39 \\
& BUMN & 41 & 16,02 & 0,66 \\
\hline
\end{tabular}

Sumber: data diolah, 2018

Total sampel penelitian ini adalah 454 observasi tahun perusahaan (terdiri dari 41 observasi BUMN dan 413 observasi perusahaan swasta) dari tahun 2014 sampai dengan tahun 2016. Dari tabel 1 ditunjukkan bahwa rata-rata dari tingkat tata kelola perusahaan (CGI) BUMN adalah 19,06 lebih tinggi dibandingkan tingkat tata kelola perusahaan swasta yaitu 15,77 


\section{Uji Asumsi Klasik}

Uji Normalitas

Hasil uji normalitas pada tabel 2 menunjukkan bahwa nilai Kolmogorov-Smirnov untuk model Z sebesar 0,806 dan nilai signifikansinya adalah 0,535 .

Dari hasil pengujian, diperoleh hasil yang menunjukkan bahwa data telah terdistribusi normal sehingga dapat dilakukan pengujian asumsi klasiknya sebelum melakukan pengujian hipotesis.

Tabel 2 Hasil Uji Normalitas Model 1

\begin{tabular}{|l|c|c|c|}
\hline & $\begin{array}{c}\text { Kolmogorov-smirnov } \\
\mathrm{Z}\end{array}$ & P.Sig & Keterangan \\
\hline $\begin{array}{l}\text { Unstandardized } \\
\text { residual }\end{array}$ & 0,806 & 0,535 & Normal \\
\hline
\end{tabular}

Sumber: data diolah, 2018

Uji Heteroskedastisitas

Tabel 3 Hasil Uji Heterokedatisitas

\begin{tabular}{|l|c|c|l|}
\hline \multicolumn{1}{|c|}{ Variabel } & T hitung & P.Sig & \multicolumn{1}{c|}{ Keterangan } \\
\hline BUMN & $-3,329$ & 0,005 & Heterokedastisitas \\
\hline ROA & 0,405 & 0,686 & Bebas Heterokedastisitas \\
\hline LEVERAGE & $-1,231$ & 0,219 & Bebas Heterokedastisitas \\
\hline SIZE & $-1,575$ & 0,116 & Bebas Heterokedastisitas \\
\hline GROWTH & 1,017 & 0,310 & Bebas Heterokedastisitas \\
\hline SB & 1,573 & 0,117 & Bebas Heterokedastisitas \\
\hline
\end{tabular}

Sumber: data diolah, 2018

Dari tabel3dapat dilihat bahwa masih terdapat sedikit masalah heterokedastisitas di model penelitian. Upaya untuk menyembuhkan masalah heterokedastisitas telah dilakukan, namun hasil pengujian menunjukkan tetap terjadi masalah heterokedastisitas di salah satu variabel di model 1. Namun masalah heterokedastisitas dalam model ini mungkin bisa sedikit diabaikan dikarenakan penelitian ini menggunakan data panel sebagai objek penelitian.

\section{Uji Multikolinieritas}

Tabel 4 Hasil uji Multikolinearitas

\begin{tabular}{|l|c|c|l|}
\hline \multicolumn{1}{|c|}{ Variabel } & Tolerance & VIF & \multicolumn{1}{c|}{ Keterangan } \\
\hline BUMN & 0,881 & 1,135 & Bebas Multikolineritas \\
\hline ROA & 0,857 & 1,167 & Bebas Multikolineritas \\
\hline LEVERAGE & 0,899 & 1,112 & Bebas Multikolineritas \\
\hline
\end{tabular}




\begin{tabular}{|l|l|l|l|}
\hline SIZE & 0,437 & 2,291 & Bebas Multikolineritas \\
\hline GROWTH & 0,978 & 1,023 & Bebas Multikolineritas \\
\hline SB & 0,460 & 2,174 & Bebas Multikolineritas \\
\hline
\end{tabular}

Sumber: data diolah, 2018

Dari uji multikolinearitas dapat dilihat bahwa semua variabel memiliki nilai tolerance lebih besar dari 0,1 dan nilai VIF kurang dari 10. Sehingga dapat disimpulkan bahwa tidak terjadi multikolinearitas antar variable.

Uji Autokorelasi

Tabel 5 Hasil uji Autokorelasi

\begin{tabular}{|l|l|l|l|l|}
\hline Durbin Watson & $\mathrm{dU}$ & $4-\mathrm{dU}$ & Kesimpulan & Keterangan \\
\hline 1,905 & 1,86774 & 2,13226 & $\mathrm{dU}<\mathrm{DW}<4-\mathrm{dU}$ & Bebas Autokorelasi \\
\hline
\end{tabular}

Sumber: data diolah, 2018

Dari hasil pengujian autokorelasi model 1, diperoleh nilai DW pada tabel 5 sebesar 1,905. Dari hasil uji autokorelasi menunjukkan bahwa nilai DW berada diantara atas (dU) dan (4-dU) artinya tidak ada hubungan atau korelasi antar residual.

\section{Uji Hipotesis}

\section{Hasil Analisis Regresi}

Tabel 6 Koefisien Determinasi $\left(\mathbf{R}^{2}\right)$

\begin{tabular}{|c|c|}
\hline Model & Adusted R \\
\hline 1 (Tata Kelola Perusahaan) & 0,373 \\
\hline
\end{tabular}

Sumber: data diolah, 2018

Pada tabel 6 menunjukkan bahwa nilai $\mathrm{R}^{2}$ model 1 adalah sebesar 0,373 atau 37,3\%. Dan $62,7 \%$ sisanya dipengaruhi oleh variabel lain yang tidak terdapat dalam model.

Tabel 7 Uji Signifikansi Parameter Individual (Uji Statistik t)

\begin{tabular}{|l|c|c|c|c|c|}
\hline Variabel & $\begin{array}{c}\text { Unstadardized } \\
\text { coefficient }\end{array}$ & $\begin{array}{c}\text { Standardized } \\
\text { coefficient }\end{array}$ & $\mathrm{t}$ & Sig. & Keterangan \\
\hline BUMN & $\mathrm{B}$ & Beta & & & \\
\hline ROA & 2,463 & 0,369 & 9,708 & 0,000 & Signifikan \\
\hline LEVERAGE & $-0,009$ & 0,022 & 0,618 & 0,010 & Signifikan \\
\hline SIZE & 0,390 & $-0,032$ & $-0,896$ & 0,349 & Tidak Signifikan \\
\hline GROWTH & $-0,007$ & $-0,334$ & 6,394 & 0,000 & Signifikan \\
\hline SB & 0,142 & 0,103 & $-5,740$ & 0,000 & Signifikan \\
\hline
\end{tabular}

Sumber: data diolah, 2018 
Uji signifikansi parameter individual (uji statistik t) dignakan untuk menguji seberapa jauh pengaruh masing-masing variabel independen secara individu menjelaskan variasi variabel dependen (Ghozali, 2011). Hasil uji t pada tabel 7 dapat diperoleh kesimpulan sebagai berikut.

Hasil analisis pada pengujian hipotesis mengenai tata kelola perusahaan BUMN dan perusahaan swasta ditunjukkan dalam tabel 7. Koefisien dan nilai signifikansi dari BUMN menunjukkan nilai positif dan signifikan pada level $1 \%$. Hal ini mengindikasikan bahwa Hipotesis terdukung.

Variabel kontrol leverage terlihat tidak berpengaruh pada penerapan tata kelola perusahaan di suatu perusahaan. Sebaliknya, variabel ROA, size dan jumlah saham beredar berpengaruh positif signifikan (signifikan pada level 1\%) terhadap penerapan tata kelola perusahaan. Sedangkan variabel growth berpengaruh negatif signifikan terhadap penerapan tata kelola perusahaan (signifikan pada level 1\%). Dengan demikian dapat disimpulkan bahwa BUMN memiliki tingkat penerapan tata kelola perusahaan yang lebih baik dibandingkan perusahaan swasta. Pengurangan kepemilikan pemerintah pada suatu BUMN diharapkan dapat mengurangi masalah multi-prinsip (Jiang et al., 2008) dan meningkatkan tata kelola perusahaan dan efisiensi pasar saham (Yu, 2013). Strategi pengurangan kepimilikan negara pada suatu BUMN dapat menghapus pembatasan perdagangan pada saham yang tidak dapat diperdagangkan. Akibatnya, kekayaan pemegang saham negara menjadi lebih sensitif terhadap pergerakan harga saham, dan konflik kepentingan mereka dengan pemegang saham swasta dan asimetri informasi telah berkurang (Hou et al., 2012).

Size berpengaruh positif signifikan terhadap tata kelola perusahaan. Hal ini konsisten dengan beberapa penelitian sebelumnya (misalnya Djankov \& Murrell, 2002; Chang dan Boontham, 2017). Hal ini berarti menunjukkan bahwa semakin besar ukuran perusahaan maka perusahaan cenderung akan lebih baik dalam menerapkan tata kelola perusahaannya. Sedangkan berkaitan dengan kinerja pasar hal ini menunjukkan bahwa ketika perusahaan memiliki aset yang kecil kinerja pasarnya lebih optimal. Variabel growth berpengaruh signifikan terhadap tata kelola perusahaan. Hasil ini konsisten dengan hasil penelitian Khatab et al. (2011). 
Jumlah saham beredar terlihat berpengaruh positif signifikan terhadap penerapan tata kelola perusahaan. Hal ini menunjukkan bahwa semakin besar jumlah saham perusahaan yang beredar maka penerapan tata kelola perusahaan menjadi lebih baik pula. Hal ini sejalan dengan teori pensinyalan, dimana semakin banyak perusahaan menawarkan saham ke publik maka menjadi sebuah sinyal yang baik kepada para investor yang menunjukkan bahwa perusahaan memiliki tata kelola yang baik sehingga terus menambah saham yang ditawarkan ke publik.

\section{KESIMPULAN}

Hasil penelitian ini menunjukkan hasil yang konsisten dengan beberapa penelitian sebelumnya yang menemukan bahwa BUMN yang telah diprivatisasi memiliki tingkat penerapan tata kelola perusahaan dan kinerja pasar yang lebih baik dibandingkan dengan perusahaan swasta. Hal ini menunjukkan bahwa strategi pemerintah untuk melakukan privatisasi pada BUMN melalui IPO telah tepat. Pengurangan porsi kepemilikan pemerintah pada suatu BUMN dikatakan dapat dapat meningkatkan tata kelola perusahaan dan efisiensi pasar saham.

Strategi pengurangan kepimilikan negara pada suatu BUMN dapat menghapus pembatasan perdagangan pada saham yang tidak dapat diperdagangkan. Akibatnya, kekayaan pemegang saham negara menjadi lebih sensitif terhadap pergerakan harga saham, dan konflik kepentingan mereka dengan pemegang saham swasta dan asimetri informasi telah berkurang. Dengan demikian, dapat dikatakan bahwa penjualan sebagian saham BUMN ke publik (privatisasi) telah memainkan peran positif dalam memoderasi hubungan antara kepemilikan negara dan rasio profitabilitas perusahaan. Hasil penelitian mendukung teori property right, teori keagenan dan teori pensinyalan yang digunakan oleh perusahaan khususnya bagi BUMN yang telah diprivatisasi untuk meningkatkan tingkat penerapan tata kelola perusahaan dan kinerja pasar perusahaan.

\section{KETERBATASAN DAN SARAN}

Keterbatasan yang ditemui dalam melakukan penelitian adalah Jumlah BUMN yang terdaftar di Bursa Efek Indonesia masih sangat sedikit dibandingkan dengan perusahaan swasta, hal ini juga dikarenakan dengan relatif pendeknya periode penelitian ini. 


\section{DAFTAR PUSTAKA}

Bai, C.-E., Lu, J., \& Tao, Z. (2009). How does privatization work in China? Journal of Comparative Economics, 453-470.

Black, B. S., Jang, H., \& Wooochan, K. (2003). Does Corporate Governance Affect Firm Value? Evidence from Korea. Finance Working Paper.

Bruton, G. D., Peng, M. W., Ahlstrom, D., Stan, C., \& Xu, K. (2015). State-Owned Enterprises Around The As Hybrid Organization. The Academy of Management Perspectives, 92-114.

Chang, S.-C., \& Boontham, W. (2017). Post-privatization speed of state ownership relinquishment: Determinants and influence on firm performance. North American Journal of Econmoics, 82-96.

Claessens, S., \& Yurtoglu, B. B. (2013). Corporate Governance in Emerging Markets: A Survey. Emerging Markets Review, 1-33.

DeWenter, K. L., \& Malatesta, P. H. (2001). State-Owned and Privately Owned Firms: An Empirical Analysis of Profitability, Leverage, and Labor Intensity. American Economic Review, 91(1): 320-334.

Ding, Yuan., Zhang, Hua., \& Zhang, Junxi. (2007). Private vs State Ownership and Earnings Management: Evidence From Chinese Listed Companies. Corporate governance.

Djankov, S., \& Murrell, P. (2002). Enterprise restructuring in transition: A quantitative survey. Journal of Economic Literature, 40, 739-792.

Eisenhardt, K. M. (1989). Building Theories from Case Study Research. The Academy of Management Review, 532-550.

Ghozali, I. (2011). Aplikasi Analisis Multivariete dan Ekonometrika: Teori, Konsep dan Aplikasi dengan Eviews 8. Semarang: UNDIP.

Hou, W., Kuo, J.-M., \& Lee, E. (2012). The impact of state ownership on share price informativeness: The case of the Split Share Structure Reform in China. The British Accounting Review, 248-261.

Ischak, M. A. (2002). Perbandingan Kinerja Keuangan BUMN dan Perusahaan Swasta di BEJ. Thesis Univrsitas Gadjah Mada Yogyakarta.

Jensen, M., \& Meckling, W. (1976). Theory of the Firm : Managerial Behavior, Agency Costs and Ownership Structure. Journal of Financial Economics, 305-360.

Jiang, B. B., Laurences, J., \& Tang, K. K. (2008). Share reform and the performan ce of China's listed companies. China Economic Review 19(3), 489-501.

Kamal, Miko. (2010). Konsep Corporate Governance di Indonesia: Kajian atas Kode Corporate Governance. Jurnal Manajemen Teknologi.

Kemenkeu. (2016). Partisipasi BUMN pada Amnesti Pajak Belum Maksimal. Jakarta: Kemenkeu.go.id.

Khatab, Humera., Masood, Maryam., Zaman, Khalid., \& Saeed, Bilal. (2011). Corporate Governance and Firm Performance: A Case study of Karachi Stock Market. International Journal of Trade, Ecinomics and Finance, 2(1), 39-43.

Kurniawan, D. M. (2000). Corporate Governance in Indonesia. Hong kong, China: OECD.

Liu, Y., Miletkov, M. K., Wei, Z., \& Yang, T. (2014). Board Independence and Firm Performance in China. Journal of Corporate Finance.

Mardiasmo. (2009). Akuntansi Sektor Publik. Yogyakarta: ANDI.

Monks, R. A., \& Minow, N. (2003). Corporate Governance. Blackwell Publishing. 
Munawarah, Muhammad, D., Zainuddin, F., \& Muharram, H. (2017). What Effects Do Privatisation Policies Have on Corporate Governance of State-Owned Enterprises? European Research Studies, 124-132.

Peng, M. W., Bruton, G. D., Stan, C. V., \& Huang, Y. (2016). Theories of the (state-owned) firm. Asia Pac J Manag, 293-317.

PriceWaterhouseCoopers. (2000). Corporate Governance: 1999 Survey of Institutional. PWC.

Primadhyta, S. (2017). Perusahaan BUMN Rugi, Direksinya Bakal Dipecat. CNNINDONESIA.

Siregar, S. V., \& Utama, S. (2008). ype of earnings management and the effect of ownership structure, firm size, and corporate-governance practices: Evidence from Indonesia. The International Journal of Accounting, 1-27.

Tong, S. Y. (2009). Why privatize or why not? Empirical evidence from China's SOEs reform. China Economic Review, 402-413

Tong, S., Junarsin, E., \& Li, C. (2015). A Comparative Study of Chinese SOE Firm's Boards and Private Firm's Board. Annals Of Economics And Finance, 291-314.

$\mathrm{Yu}$, M. (2013). State ownership and firm performance: Empirical evidence from Chinese listed companies. China Journal of Accounting Research. 